\title{
Preface for Special Section on Archaeoparasitology: A Global Perspective on Ancient Parasites and Current Research Projects
}

\author{
Jong Yil Chail ${ }^{1,2, *}$, Min Seo ${ }^{3}$, Karl Reinhard ${ }^{4}$, Dong Hoon Shin ${ }^{5}$ \\ ${ }^{1}$ Department of Tropical Medicine and Parasitology, Seoul National University College of Medicine, Seoul 03080, Korea; '2Institute of Parasitic \\ Diseases, Korea Association of Health Promotion, Seoul 07649, Korea; ${ }^{3}$ Department of Parasitology, Dankook University College of Medicine, \\ Cheonan, Korea; ${ }^{4}$ School of Natural Resource Sciences, University of Nebraska, Lincoln, USA; ${ }^{5}$ Department of Anatomy and Cell Biology, \\ Seoul National University College of Medicine, Seoul 03080, Korea
}

Archaeoparasitological research has rapidly developed in recent years, entering a new stage of improved understanding of our ancestors' parasitic infections across the world. This progress is based on a variety of recently developed research techniques. During a period of rapid innovation since 2016, there has been no much opportunity for parasitologists to gather and share in-depth views about this novel research field. This was remedied by the 14th International Congress of Parasitology (ICOPA) held in Korea (Aug. 19-24, 2018; EXCO, Daegu). For archaeoparasitologists, ICOPA provided a unique opportunity to gather and exchange research and ideas. The participation was unprecedented in numbers of attendees and diversity of papers presented. Three sessions were organized under the unified theme of "A global perspective on ancient parasites: current research projects". In the sessions, a number of landmark studies were presented by parasitologists, archaeologists, and paleopathologists from South Korea as well as many other countries worldwide.

During the last decades, the summaries of significant advances in theory and method have periodically appeared in different journal special issues dedicated to archaeoparasitology [1-3]. The case studies from these issues improved our understanding of the history of parasites and the diversity of parasite populations over time. However, since most recently, research expanded geographically as well as methodologically,

- Received 6 October 2019, revised 9 October 2019, accepted 9 October 2019.

*Corresponding author (cjy@snu.ac.kr)

(c) 2019. Korean Society for Parasitology and Tropical Medicine

This is an Open Access article distributed under the terms of the Creative Commons Attribution Non-Commercial License (http://creativecommons.org/licenses/by-nc/4.0) which permits unrestricted non-commercial use, distribution, and reproduction in any medium, provided the original work is properly cited. now is a fitting time to update the field in a new, dedicated volume. Therefore, to commemorate the event of ICOPA in Korea, and to present some of the most informed trends in archaeoparasitology, we planned the publication of a special issue under the title "A global perspective on ancient parasites and current research projects."

Multiple articles in this special issue address the emergence of ancient parasitism, infection maintenance, and disease decline in different human groups. For East Asia, Zhan et al. traced the change of parasite infection rates in China and Korea for the past 2,000 years. They observed that the prevalence of Clonorchis sinensis in Korea and China dropped earlier than did Ascaris lumbricoides and Trichuris trichiura during the 20th century. Yeh et al. also did a detailed research on the parasitism prevalent among Japanese police officers in Taiwan from 1920 to 1944 , by the examination of latrine samples from the police station site. Seo et al. dealt with the late 19th century clinical report of Horace N. Allen, a physician and an American Presbyterian missionary. Allen once described many hemoptysis cases of Korean outpatients, assuming that they might have been mostly caused by paragonimiasis. Authors revisited the Allen's assumption with clinical parasitological data recently obtained from Joseon period mummies.

Some authors in this issue contributed the articles about ancient parasitism in Europe. Eskew et al. revealed the species of parasites that affected the inhabitants of the city of Acre during the Ottoman Period, by the analysis of the latrine sediment of the Ottoman Empire dating to the early 1800s. Dufour et al. carried out research on 5th to 9th century Merovingian specimens. They revealed the presence of gastrointestinal parasites, contributing to a better knowledge of parasitism among an- 
cient medieval European populations. Roche et al. also reported a parasitological study on the samples from the 4th to 5th century Florentine graves of Italy, showing how parasitological information could be retrieved from the analysis of sediments sampled in cemeteries.

Slepchenko et al. reported on ancient parasitism in Siberia. In their study, parasitological comparison of ancient samples with contemporary ones can provide insight into the changing pattern of parasitism among Arctic or subarctic population of Western Siberia. They also analyzed the soil samples of the 13th to 18th century Nadym Gorodok site in the permafrost area of Siberia and deduced that raw or undercooked fish were enjoyed by the far north inhabitants about 400 years ago. As for archaeoparasitology of North America, Camacho and Reinhard reported their parasitological analysis of coprolite deposits from Salmon and Aztec Ruins, the 12th to 13th century defensible towns that survived periods of crisis by virtue of large populations. This is the final study in a series of works dedicated to Enterobius vermicularis that addressed quantification, taphonomy and epidemiology of infection. The basic question through all of these studies was why infection reached unprecedented levels in the Pueblo III study region and time. Population aggregation in response to warfare is the most likely explanation.

In this special section, some articles also reported errors that are easy to commit or the technical tips to be employed during archaeoparasitological studies. In brief, Camacho and Reinhard warned the possible risk of confusing pollen grains with helminth eggs from archaeological sites because some pollen grain types are similar to parasite eggs. They highlighted that the interdisciplinary approach to archaeoparasitology, which was its foundation in the 20th century, has been lost in the last decades. Morrow et al. also described that confocal laser scan- ning microscopy (CLSM) provided useful data for challenging identification of ancient parasite egg by highlighting subtle morphological features and enhancing visualization of parasite egg anatomy.

Cumulatively, these papers illustrate the rapid diversification of archaeoparasitology, revealing a variety of past infection patterns among human populations in history and prehistory. The growth of the field came about through the application of varied investigative techniques. As the discipline expands globally, study topics have become more distinct and nuanced. As a result, there is a need for comprehensive synthesis of the research from all over the world. We approached ICOPA and this volume as a step towards accomplishing this important goal. In this regard, the current special issue is an important resource for future researchers. It confirms that parasitological studies of archaeological specimens are no longer isolated to in any one country or on the continent. Before this special section was compiled, Adauto Araújo and Luiz Fernando Ferreira, the first cohort of scholars who dedicated their lives to investigating the origin and spread of parasite infections in antecedent human cultures, sadly passed away. We deeply missed these incomparable colleagues and mentors who provided inspiration and guidance to many of archaeoparasitologists around the world.

\section{REFERENCES}

1. Combes C. Paleoparasitology. Mem Inst Oswaldo Cruz 2003; 98 (suppl): 1-2.

2. Buikstra JE. EIC Editorial: Introducing the paleoparasitology issue. Int J Paleopathol 2013; 3: 139.

3. Chai JY, Seo M, Shin DH. Preface for special section on paleoparasitology. Korean J Parasitol 2016; 54: 553-554. 